\title{
Effect of Organic Nutrition in the Nursery Growth and Nutrimental Content of Native Avocados of Ometepec, Guerrero, Mexico
}

\author{
Damián-Nava A. ${ }^{1}$, Arellano-Roque L. ${ }^{1}$, Hernández-Castro E. ${ }^{1}$, Palemón-Alberto F. ${ }^{1}$, Cruz- \\ Lagunas B. ${ }^{2}$, Vargas-Álvarez D. ${ }^{1}$, Díaz-Villaseñor G. ${ }^{2}$, Leiva-Rojo E. I. ${ }^{3}$ andRamírez-Pisco \\ $\mathrm{R}^{3}$
}

${ }^{1}$ Postgraduate in Agricultural Science and Local Management, Autonomous University of Guerrero. Iguala-Tuxpan Hwy, Km. 2.5. Iguala, Guerrero, Mexico. C.P. 40101.

${ }^{2}$ Academic Unit of Agricultural and Environmental Sciences of the Autonomous University of Guerrero. Iguala-Tuxpan Hwy, Km. 2.5. Iguala, Guerrero, Mexico. C.P. 40101.

${ }^{3}$ Faculty of Agricultural Science and ${ }^{3}$ Faculty of Sciences of the National University of Colombia, campus Medellín of Antioquia, Colombia.

\begin{abstract}
In Mexico, there are several types of wild and criollo avocados that constitute a genetic heritage of this species; these avocados currently grow in an unordered manner on farmer's lands and in backyards, and they need to be studied as they are being lost because of agricultural activities and edaphoclimatic and phytosanitary factors. On the other hand, in orchards and avocado nurseries, high amounts of chemical fertilizers and pesticides are used affecting the physicochemical and microbiological properties of the soil, modifying the flora and fauna and polluting aquifers and springs that cause health problems among consumers. Therefore, it is very important to have a more friendly agriculture with the nature. The aim of this work was to evaluate under nursery conditions, the effect of organic fertilizers on 12 genotypes (rootstocks) of native avocados of Ometepec, Guerrero, Mexico, under an experimental design of random blocks, with four treatments: T1: sheep manure,T2: Bovine manure, T3: mycorrhizae and T4 (control: water) in four replicates. The variables were: plant height $(P H)$, stem diameter $(S D)$, number of leaves: young (NYL) and mature (NML) per plant; and the content of $\mathrm{NO}_{3}^{-}, \mathrm{K}^{+}, \mathrm{Ca}^{2+}$ and $\mathrm{Na}^{+}$ions obtained by petiole extraction, and the chlorophyll content measured with $S P A D$, in young $(C Y L)$ and mature $(C M L)$ leaves. Additionally, an analysis of variance and Tukey mean tests $(P \leq 0.01$ and 0.05$)$ and $\operatorname{LSD}(P \leq 0.05)$ were done. It was found that sheep manure was superior to other treatments in $P H(76.7 \mathrm{~cm}), S D(7.2 \mathrm{~mm}), \quad N Y L$ (6.5 leaves/plant), NML (18.4 leaves/plant), CML (40.2 SPAD) and $\mathrm{Ca}^{2+}(1495 \mathrm{ppm})$. In conclusion, the sheep manure was
\end{abstract}

better than the bovine, mycorrhiza and control (water) as it affected positively the behavior of rootstocks in plant height, stem diameter and number of young and mature leaves. In addition, organic nutrition showed no significant response in the chlorophyll content of young and mature leaves. Young leaves only reached 50\% of the chlorophyll content compared to mature leaves.

Keywords - Native Avocados, Vegetative Growth of Rootstocks, Organic Nutrition.

\section{INTRODUCTION}

In conventional agriculture, heavy doses of chemical fertilizers and pesticides are often used to correct nutrient deficiencies in soils and to improve crop yields. However, these chemicals cause health problems among consumers (Larios et al., 2011; Márquez-Quiroz et al., 2014) and to the environment, as in areas where these substances are applied, the leached water draws nitrates, that pollute aquifers and springs in avocado producing regions (Tapia $e t$ al., 2012). In this sense, it has been reported that higher concentrations than $10 \mathrm{mg} \mathrm{L}^{-1}$ of $\mathrm{N}^{-N} \mathrm{O}_{3}$ in drinking water can cause serious diseases in humans and young animals (Killpack and Bucholz, 1993); the nitrogen loss in avocado orchards increases during the raining season, July and October, and they pollute the environment as the leachatecarries out the nutrients. In the same way, irrigation contributes to this loss of chemical fertilizers as every year the traditional irrigation produced $80-96 \mathrm{mgL}^{-1}$ of $\mathrm{N}-\mathrm{NO}_{3}$ leachate, while the located irrigation only produced from 36-47 $\mathrm{mg} \mathrm{L}^{-1}$ (Tapia et al., 2012). In addition, these 
chemical fertilizers affect the physicochemical and microbiological properties of soil, as they modify its $\mathrm{pH}$, structure, aeration and porosity, as well as the flora and fauna (Trinidad et al., 2015).In the mutualistic associations, known as arbuscular mycorrhiza, the fungus colonizes the root cortex in an extra and intracellular way, developing an intricate external mycelium that surrounds the root of the colonized plants. This mycelium forms a continuous connection between the solution of the soil and the plant, which allows the uptake of ions from the soil and their transport to the root of the host. In an opposite way, the arbuscular mycorrhizalfungus (AMF) receives carbon compounds from photosynthesis of the plant, which are necessary for its metabolism because it is a symbiont, which requires interaction with the plant to complete its life cycle (Seguel, 2014). These mycorrhizal associations increase access to plant nutrients such as: phosphorus $(\mathrm{P})$, nitrogen $(\mathrm{N})$, copper $(\mathrm{Cu})$ and zinc $(\mathrm{Zn})$. The absorption, transport and transfer of $\mathrm{P}$ from the mycelium to the plant is fast and efficient due to the presence of carriers with high affinity to the $\mathrm{H}_{2} \mathrm{PO}_{4}^{-}$ion, which acts coupled with an $\mathrm{H}^{+}$ symporter carrier through various $\mathrm{H}^{+}$-ATPase. On the other hand, fungal mycelium acts in the release of nutrients from particles and mineral rocks by weathering, and also,they connect to the host plants which are the nutrients required for their growth, allowing the flow of energy-rich compounds required for the mobilization of the nutrient; additionally, they increase the absorbing surface area of the plant system, the mycorrhizal extraradical mycelium provides a direct pathway for the translocation of the carbon derived from photosynthesis to the microsites in soil and a large surface area for the interaction of other microorganisms (Finlay, 2008). In this way, the symbiotic nature of the plants with the arbuscular mycorrhizal fungi have proved to be fundamental for the sustainability of the ecosystems, since they are able to colonize large number of terrestrial plants. This technology represents an alternative to improve the soil biological balance and reduce the use of chemical fertilizers and other agrochemical compounds in the production systems (Jeffries et al., 2003).The avocado root lack of absorbent hairs; however, it has been reported that arbuscular mycorrhizal fungi (AMF) colonize the roots of this fruit tree, and that they favor water absorption and use of soil nutrients by the plant, they also promote growth and they keep the nursery plants healthy (Reyes et al., 1997; Bárcenas et al., 2007).

Published reports on AMF inoculation are scarce and they have shown a broad range of responses, ranging from zero to clear growth responses (Silveira et al., 2002), they also improve nutrition, health, growth, resistance to pathogens and tolerance to adverse conditions in the nursery. In avocado seedlings, the application of Glomus spp. Zac-19 and vermicompost favored stem height and diameter (Reyes et al., 1998); in addition, the application of a $1 \mathrm{~kg}$ fluid paste of the EcoMic ${ }^{\circledR}$ Biofertilizer and $600 \mathrm{ml}$ of water, stimulated the development of avocado rootstocks under nursery conditions, which has been reflected on plants of higher quality, and in turn they are a nutritional alternative for this crop (Rivera-Espinosa et al., 2011).Avocadosinoculated with AMFin the nursery,increased their height, diameter, and fresh and dry leaves weight; Rhizophagus fasciculatum inoculant (used in sterile soil) showed higher growth; on the contrary, Pacispora scintillans andAcaulospora laevis(on unsterilized soils), showed a decrease in plant growth (Banuelos et al., 2013). On the other hand, in avocado rootstocksinoculated with AMF in the nursery, Acaulospora delicata had better plant height and Scutellospora pellucidashowed larger stem diameter; while Rhizophagus intraradices 28-A andScutellospora pellucidaincreased twice the stem and root weight in relation to other treatments (Carreón et al., 2014).In addition, it has been reported that AMFs influence mineral nutrition and carbohydrate content in 'Carmen' avocado seedlings; in all mycorrhizal types, the inoculated plants had higher contents (mg/plant) than the control ones: S. heterogama in N, P, K, $\mathrm{Mg}, \mathrm{Cu}$ and $\mathrm{Zn}$; with G. etunicatum in $\mathrm{N}, \mathrm{P}, \mathrm{K}, \mathrm{Ca}, \mathrm{Mg}, \mathrm{Cu}$ and $\mathrm{Zn}$; with $A$. scrobiculata in $\mathrm{P}, \mathrm{Cu}$ and $\mathrm{Zn}$; and with $G$. clarum in $\mathrm{K}, \mathrm{Ca}, \mathrm{Cu}$ and $\mathrm{Zn}$. All AMF species increased the amounts of carbohydrates in plants (Silveira et al., 2003).

The State of Michoacan, Mexico, produces millions of avocado plants per year in nursery to meet the demand for new plantations at national and regional level, where their quality is highly appreciated. However, the high amounts of fertilizers and pest control products that pollute the environment have been questioned; which is why there is a need to implement new production technologies that reduce these agricultural products, such as the use of organic fertilizers and the application of arbuscular mycorrhizal fungi that have important functions in plant growth (RiveraEspinosa et al., 2011).

In avocado plantations and nurseries, high amounts of chemical fertilizers and pesticides are used which affect the physicochemical and microbiological properties of soil, they also alter its flora and fauna and because the leached water drags nitrates, then contaminated aquifers and springs cause health problems among consumers. Therefore, it is necessary to look for alternatives in the agricultural activity, more in line with practices that respect nature, that does not harm the health of the consumers and that allow to obtain 
healthy products; for this reason, the aim of this research was to study the behavior of rootstocks of native avocados in nursery and their response to organic nutrition based on bovine and ovine liquid manures and the application of mycorrhizae, in which the following objective was assessed: to evaluate the effect of organic fertilizers on 12 genotypes of native avocados of Ometepec, Guerrero.

\section{MATERIALS AND METHODS}

\section{Location of studyarea}

The study was conducted in Iguala, Guerrero, Mexico, from August to December 2015. The area is located at $757 \mathrm{~m}$ altitude, with following coordinates: $18^{\circ} 20^{\prime} 39^{\prime \prime} \mathrm{N}$ and $99^{\circ}$ 29'53" W (GPS Garmin eTrex $10^{\circledR}$ ). The climate is classified as Awo g (w) (i') (Garcia), the driest among the warm subhumids, with rains in summer (June to October), the average annual rainfall is $977.15 \mathrm{~mm}$ and the average annual temperature is $25.7^{\circ} \mathrm{C}$ (García, 1988).

\section{Methodology}

Twelve native avocado genotypes (rootstocks) from Ometepec, Guerrero, Mexico, were studied. They were one month old and grown in nurseries on substrates $(85 \%$ river mud, $5 \%$ peat moss and $10 \%$ agrolite) that were fertilized with ground (Crusher mill, CH620model, KOHLER ${ }^{\circledR}$ brand) and disinfected (stainless steel steam cooker at $120^{\circ} \mathrm{C}$ for 30 minutes)ovine and bovinemanures. Also, the commercial mycorrhiza Glumix Irrigation ${ }^{\circledR}$ Biostimulant, and water as control were used. The preparation of manures was $250 \mathrm{gL}^{-}$ ${ }^{1}$ of water and mycorrhiza of $5 \mathrm{~g} \mathrm{~L}^{-1}$ of water; the mixing and dilution of fertilizers and mycorrhizae was done with an SSP mixer [angle grinder $(230 \mathrm{~mm})(9 "), 127 \mathrm{~V}-15 \mathrm{~A}$ $50 / 60 \mathrm{~Hz} 6600 \mathrm{r} / \mathrm{min}$, Makita ${ }^{\circledR}$ brand]. The doses of manures and mycorrhiza were $250 \mathrm{~mL} /$ pot, every 30 days, with additional water irrigations every other day.

Variable recording began 15 days after the first application of treatments, then every 30 days: plant height $(\mathrm{cm})$ from neck to stem apex; diameter of stem $(\mathrm{mm})$ at $10 \mathrm{~cm}$ in height with a digital vernier (Digimatic calipbre Model: CD-12'CP, Mitutoyo ${ }^{\circledR}$ brand); number of young leaves (NYL), well-formed andnot $100 \%$ grown, and greenyellowish to reddish color; number of mature leaves (NML) with $100 \%$ growth and intense green color.In October 2015, the chlorophyll content was determined in sunny, young and mature leaves with a SPAD 502 Plus, Minolta, Model B343, Horiba ${ }^{\circledR}$ Brand. In December 2015, from 7- 10:00 am, the petiole extract was obtained from 4 mature leaves/ replicate/ treatment, from which the petiole was cut into portions that were pressed in a garlic press $\left(\mathrm{Kamp}^{\circledR}\right.$ brand); the extracted sap was deposited in the respective ionometers: $\mathrm{NO}_{3}{ }^{-}$(METER, Model B-743), $\mathrm{K}^{+}$(METER,
Model B-731), $\mathrm{Ca}^{2+}$ (METER, Model B-751) and $\mathrm{Na}^{+}$ (METER, Model B-722).

A randomized complete block design was used, which considered four treatments: T1 (sheep manure), T2 (bovine manure), T3 (mycorrhizae, Glumix Irrigation $^{\circledR}$ Biostimulant) and T4 (control,common water tap); each of them with four replicates. A variance analysis, a Tukey mean test $(\mathrm{P} \leq 0.01$ and 0.05$)$, LSD $(\mathrm{P} \leq 0.05)$, and a Pearson correlation between the variableswere carried out with the Statistic Analysis System (SAS), version 9.0.

\section{RESULTS AND DISCUSSION}

Effect of organic fertilizers on the growth and nutritional content of rootstocks

As for organic fertilizers, significant differences $(\mathrm{P} \leq 0.01)$ were observed for the following variables: plant height, stem diameter, number of leaves (young and mature) and $\mathrm{Ca}^{2+}$. However, chlorophyll in leaves (young and mature), $\mathrm{NO}_{3}^{-}, \mathrm{K}^{+}$and $\mathrm{Na}^{+}$showed no significant differences (Table 1).

\section{Plant height and stem diameter}

As for height, sheep manure showed the highest value (76.7 $\mathrm{cm}$ ) of the rootstocks and it was statistically higher than the bovine manure treatment $(73.1 \mathrm{~cm})$, which in turn was better to mycorrhizae $(69.9 \mathrm{~cm})$, which surpassed the control $(63.1 \mathrm{~cm} \mathrm{~cm})$ (Figure 1). A similar behavior was observed with the stem diameter, where the sheep manure gave the highest value $(7.2 \mathrm{~mm})$, and it exceeded the bovine fertilizer $(6.8 \mathrm{~mm})$ and mycorrhiza $(6.7 \mathrm{~mm})$, which were statistically better than the control $(6.3 \mathrm{~mm})$ (Figure 1).

In this research, the mycorrhizae treatment was surpassed by the ovine and bovine fertilizers, in height and stem diameter of the rootstocks. However, these mycorrhizae values in height of the rootstock, exceeded those reported previously $(62.6$ and $54.4 \mathrm{~cm})$ with Glomus hoi-like and Glomus mosseae (Fundora et al., 2011). Mexican avocado landrace rootstocks $(P$. americana Mill. Var. Drymifolia) inoculated with AMF, showed 32.6- $36 \mathrm{~cm}$ height values with the application of Glomus fasciculatum, $G$. constrictum, G. tortuosum, G. geosporum and Acaulospora scrobiculata (Castro et al., 2013); whereas as for diameter, in the present study it was observed slightly higher than that reported by Castro et al.(2013), who reported an average value of $8.8 \mathrm{~cm}$ in diameter with the application of various types of mycorrhizae.

\section{Number of young and mature leaves}

The sheep manure compost (6.5 leaves/ plant) showed higher value in young leaves, but it was not statistically superior to the bovine treatments (6.0 leaves/plant) or mycorrhizae (5.9 leaves/plant); it only exceeded the control 
(5.2 leaves/ plant). In relation to the number of mature leaves, sheep manure (18.4 leaves/ plant) was statistically superior to the bovine manure (17.1 leaves/ plant), mycorrhizae (17.1 leaves/ plant) and the control (16.4 leaves/ plant) (Figure 2).

However, in this study, the mycorrhizal treatment was on average as for the number of leaves/plant in comparison to other investigations with (Glomus hoi-like) 16.0 and (Glomus mosseae) 15.6 leaves/plant (Fundora et al., 2011); for consortium of Glomus fasciculatum, G. constrictum, G. tortuosum, G. geosporum and Acaulospora scrobiculata (21.9 leaves/plant); for the mixture of G. Mosseae and $G$. cubense(20.3 leaves/plant) (Castro et al., 2013).

\section{Chlorophyll content in leaves (young and mature)}

As for the chlorophyll content in young and mature leaves, the treatments did not show significant effects $(\mathrm{P} \leq 0.01)$ (Figure 3). However, it is important to mention that young leaves only had half of the chlorophyll content in comparison to mature leaves; maybe because they did not have $100 \%$ of the size and they had a coloration between yellowish- green and reddish- green. Therefore, they did not reach their maximum photosynthetic rate (Salisbury and Ross, 1994)due to the immaturity of the stomata (Faust, 1989).In coffee plants, values similar to those found in the present research (40 SPAD units) were reported in adult leaves (Torres-Netto et al., 2005); as well as in papaya (Carica papaya L.) (Torres-Netto et al., 2002); coffee (Coffea canephora P.) (Torres-Netto et al., 2005); cotton (Gossypium hirsutisms L.) (Brito et al., 2011); pine nut (Jatropha curcas L.) (Gonsiorkiewicz et al., 2013); in rice cv. Bing 9363, at the beginning and at panicle maturation, with 40.4 and 35.5 (SPAD units), respectively (Jinwen et al., 2011). In the Hass and Edrenol avocado varieties on patterns of Allesbeste Nursery, Duiwelkloof, of one year old, the chlorophyll content in mature leaves was slightly higher than those obtained in this work, it ranged from 4857 SPAD units (Bekker et al., 2005).

\section{Nutritional content per extract of petiole in treatments}

In avocado plants, the nitrate content was extracted in the petiolate where the mycorrhizal treatment was higher (3778 $\mathrm{mg} \mathrm{L}^{-1}$ ), but it was not statistically different from the other treatments, sheep manure $\left(3200 \mathrm{mg} \mathrm{L}^{-1}\right)$, bovine manure (3099 $\mathrm{mg} \mathrm{L}^{-1}$ ) and control (2144 $\mathrm{mg} \mathrm{L}^{-1}$ ) (Figure 4). The results of this research are not similar to those reported for Hass avocado from "El Rosario", municipality of Nuevo Parangaricutiro, Michoacán, where it was found that the $\mathrm{N}$ $\mathrm{NO}_{3}$ content in leaves was $24.1,32.1,25.3$ and $47.1 \mathrm{mg} \mathrm{L}^{-1}$, with the application of a fish derivative, organic compost, microorganisms (Glomus sp. and Azospirillum sp) and vermicompost, respectively (Tapia et al., 2014).In other plant species,lower nitrate contents have been reported to those found in this research; in poblano chili pepper cv. San Luis in Guanajuato, México, $500 \mathrm{mg} \mathrm{L}^{-1}$ (CastellanosRamos et al., 2001) and $1050 \mathrm{mg} \mathrm{L}^{-1}$ of $\mathrm{N}^{-N_{3}} \mathrm{O}_{3}$ were reported(Brizuela-Amador et al., 2005), whereas in tomato, $2090 \mathrm{mg} \mathrm{L}^{-1}$ (Leyva et al., 2005). This suggests that the photosynthetic rate may be high because the nitrogen content is high (Calderón, 1998) and there is a direct relationship between nitrogen and leaf chlorophyll.

The control treatments (2658 $\mathrm{mg} \mathrm{L}^{-1}$ ), mycorrhizae (2658 $\mathrm{mg} \mathrm{L}^{-1}$ ) and bovine manure (2642 $\mathrm{mg} \mathrm{L}^{-1}$ ) (Figure 4), gave potassium results similar to those reported in avocados with the application of Solupotasse (2329.2 $\left.\mathrm{mg} \mathrm{L}^{-1}\right)$, Solupotasse + Foliar Solup (2512.0 mg L ${ }^{-1}$ ), Granupotasse (2391.7 mg $\mathrm{L}^{-1}$ ) and Granupotasse + Foliar Solup (2204.2 $\mathrm{mg} \mathrm{L}^{-1}$ ) (Tapia et al., 2007); but they differ from those reported in avocado Hass from "El Rosario", Nuevo Parangaricutiro municipality, Michoacán, where it was found that the $\mathrm{K}^{+}$content in the leaves was $30.8,24.4,26.7$ and $54.6 \mathrm{mg} \mathrm{L}$ ${ }^{1}$, with the application of fish derivative, organic compost, microorganisms (Glomus sp. and Azospirillum sp) and vermicompost, respectively (Tapia et al., 2014). However, sheep manure (3113 $\mathrm{mg} \mathrm{L}^{-1}$ ) showed values higher than those reported in other studies; the differences observed in potassium can be attributed to the variation throughout the yearof temperature, solar radiation and/or relative humidity, in which high and low potassium contents are found according to the seasons (Aguilera et al., 2005).

The sheep manure treatment gave higher calcium content (1496 mg L ${ }^{-1}$ ), which exceeded the control (200 $\left.\mathrm{mg} \mathrm{L}^{-1}\right)$, but it was statistically similar to bovine manure $\left(530 \mathrm{mg} \mathrm{L}^{-}\right.$ ${ }^{1}$ ) and mycorrhizae (495 $\left.\mathrm{mg} \mathrm{L}^{-1}\right)$, respectively (Figure 4).

As for sodium, all treatments were statistically similar: mycorrhizae (1783 $\mathrm{mg} \mathrm{L}^{-1}$ ), sheep manure (1475.1 $\mathrm{mg} \mathrm{L}^{-1}$ ), bovine manure (1466.7 $\mathrm{mg} \mathrm{L}^{-1}$ ) and control (1321.7 $\mathrm{mg} \mathrm{L}^{-}$

$\left.{ }^{1}\right)$. Castro et al. (2000) reported lower values for sodium in Nabal, Duke 7 and UCV 7 avocado varieties: $200 \mathrm{mg} \mathrm{L}^{-1}$, $300 \mathrm{mg} \mathrm{L}^{-1}$ and $400 \mathrm{mg} \mathrm{L}^{-1}$, respectively.

\section{Conclusions}

- The sheep manure affected positively the behavior of rootstocks in plant height, stem diameter, number of young and mature leaves of native avocados of Ometepec, Guerrero.

- The use of organic nutrition did not show a significant response in the chlorophyll content of young and mature leaves.

- Young leaves only reached $50 \%$ of chlorophyll content compared to mature leaves. 


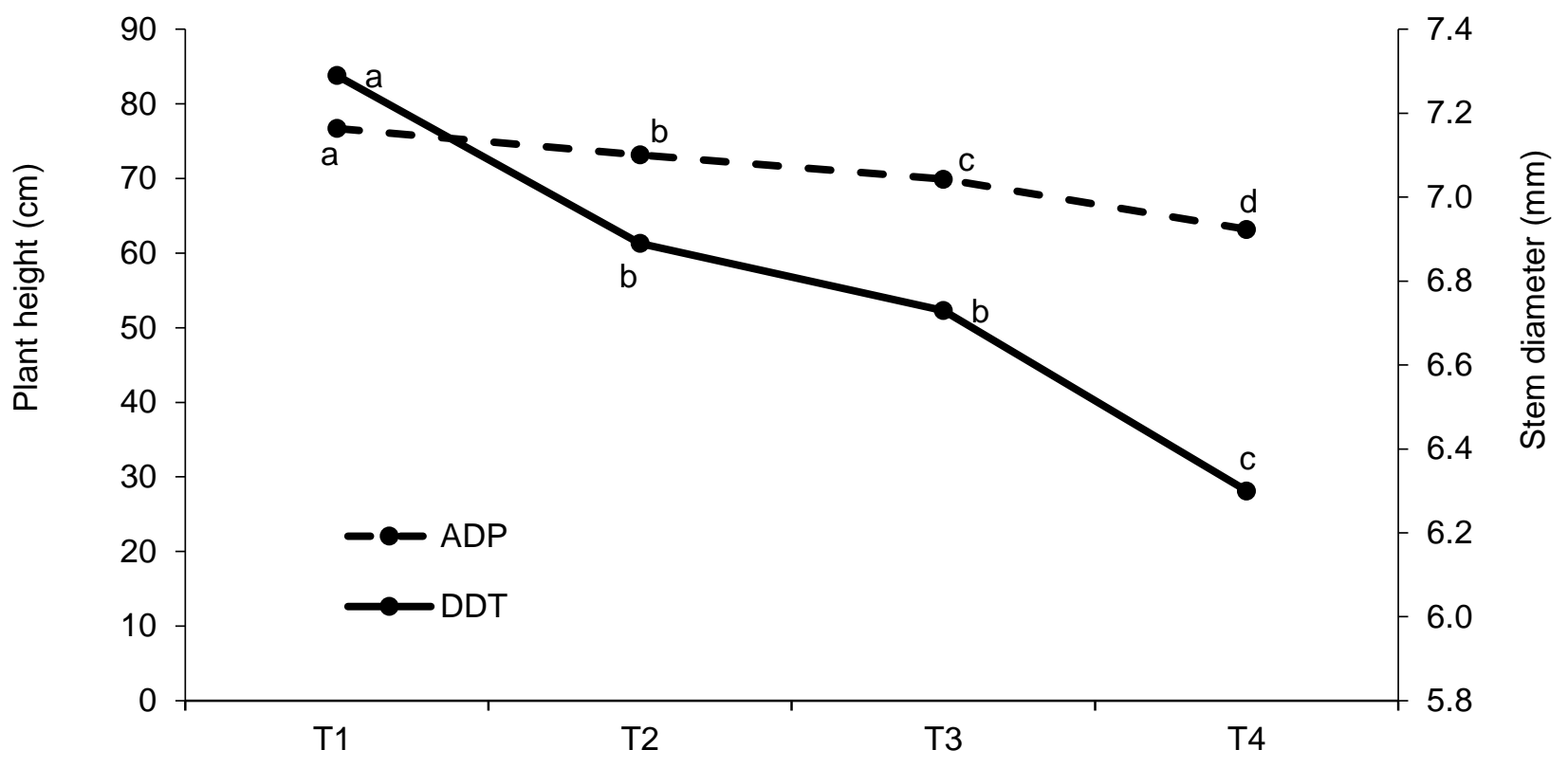

Treatments of organic nutrition

Fig.1: Organic nutrition effect in plant height (PH), stem diameter (SD of genotypes (rootstocks) of native avocados. T1: sheep manure, T2: Bovine manure, T3: mycorrhizae and T4 (control: water) in four replicates, Tukey $(P \leq 0.01)$.

hojas/planta) (Castro et al., 2013).

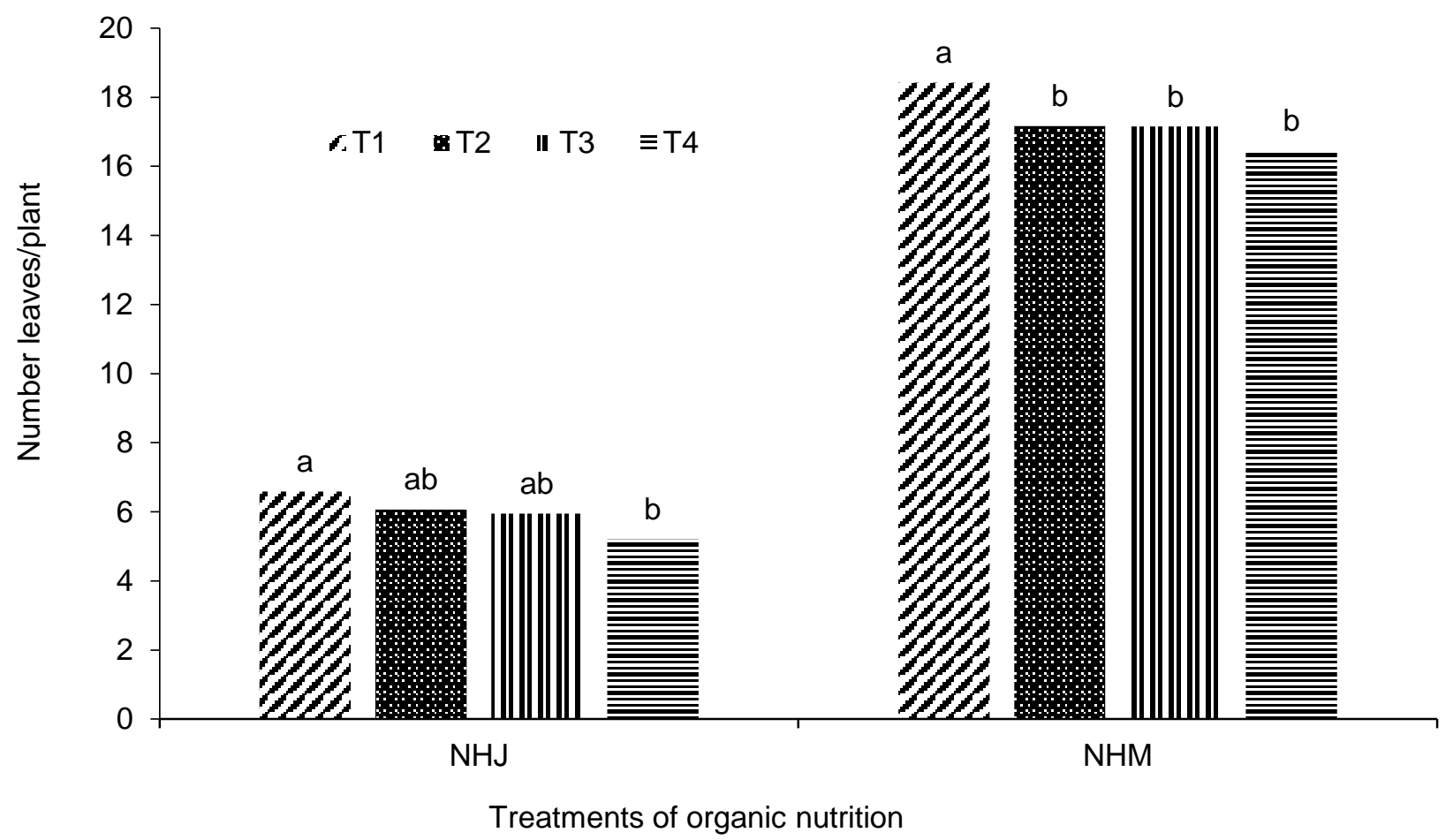

Fig.2: Effect of organic nutrition in number of young leaves (NYL) and number of mature leaves (NML) in native avocados ofOmetepec, Guerrero. $T 1$ (sheep manure), T2 (bovine manure), T3 (mycorrhizae, Glumix Irrigation ${ }^{\circledR}$ Biostimulant) and T4 (control, common water tap), Tukey $(P \leq 0.01)$.

SPAD (Bekkeret al., 2005). 


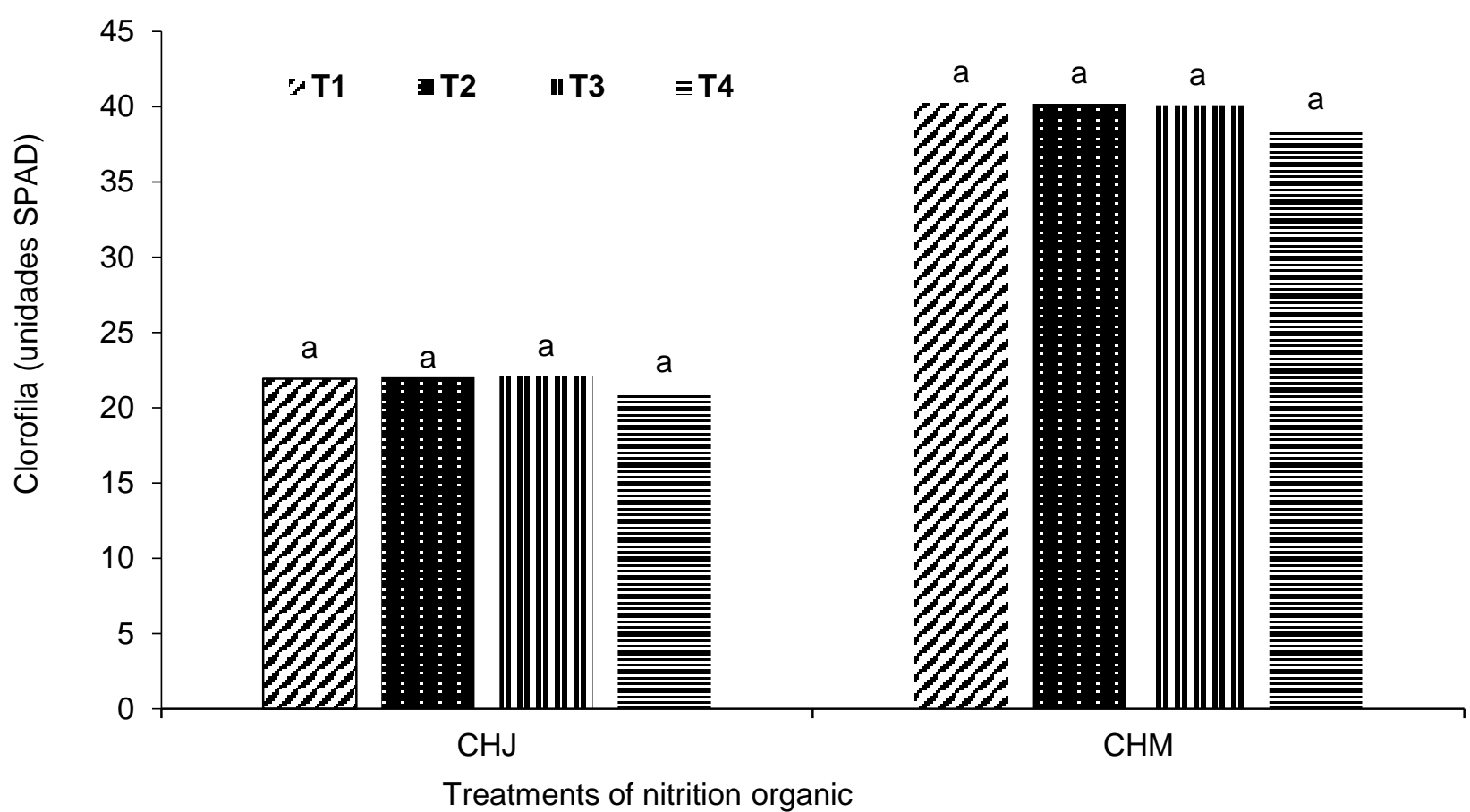

Fig.3: Effect of nitrition organic in content of chlorophyll young leaves $(C Y L)$ andchlorophyll of mature leaves $(C M L)$ in native avocados of Ometepec, Guerrero. T1 (sheepmanure), T2 (bovinemanure), T3 (mycorrhizae, GlumixIrrigation ${ }^{\circledR}$ Biostimulant) and T4 (control, commonwatertap), Tukey ( $P \leq 0.01$ ).en hojas jóvenes (CHJ) y maduras (CHM) de portainjertos de aguacates nativos del municipio de Ometepec, Guerrero. T1 (estiércol ovino), T2 (estiércol bovino), T3 (micorrizas) y T4 (testigo), Tukey $(P \leq 0.01)$.

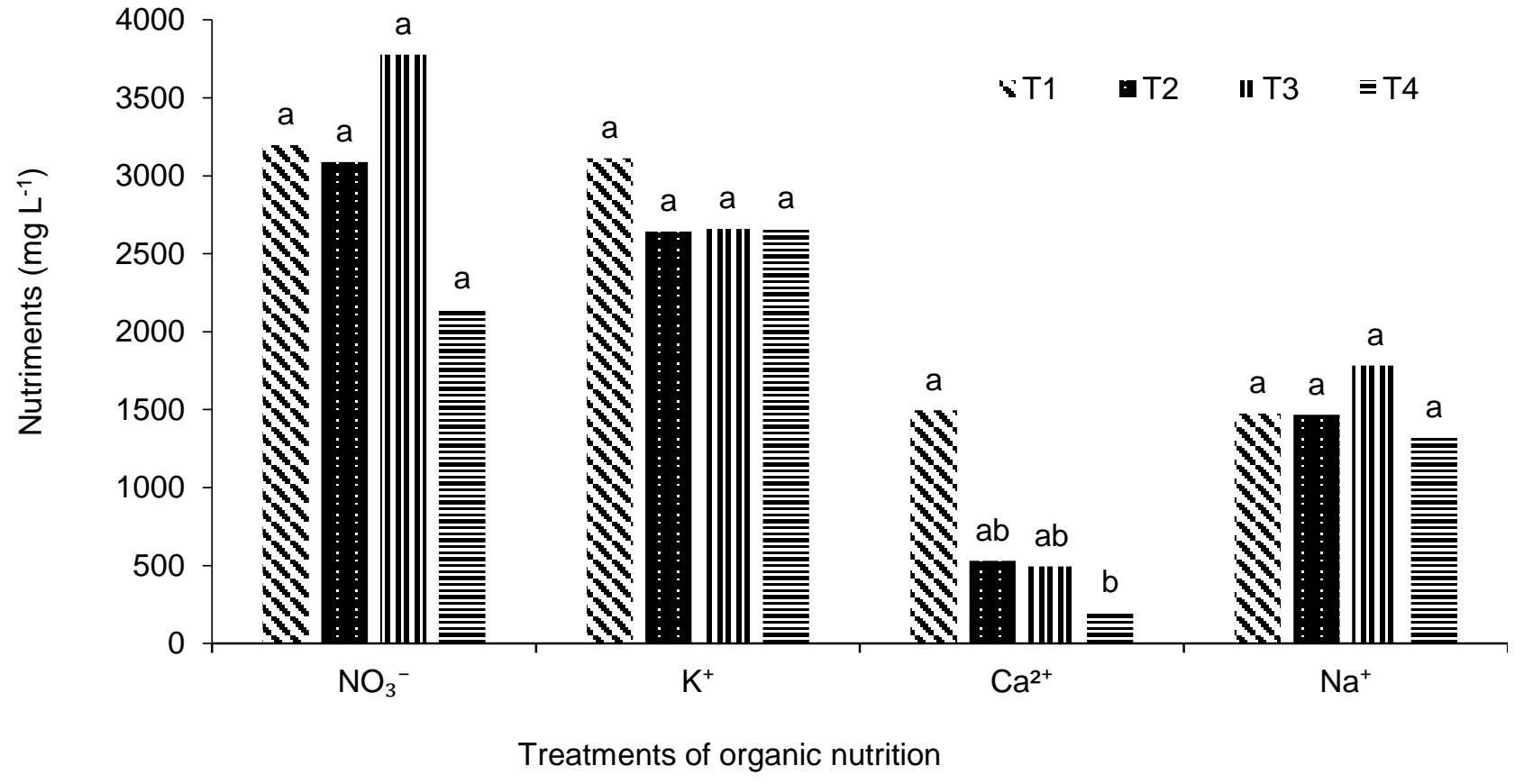

Fig.4: Effect of nutritionorganic in content of ions nitrate, potassium, calcium y sodium in native avocados of Ometepec, Guerrero. T1 (sheep manure), T2 (bovine manure), T3 (mycorrhizae, Glumix Irrigation ${ }^{\circledR}$ Biostimulant) and T4 (control, common water tap), Tukey $(P \leq 0.01)$. 


\section{REFERENCES}

[1] Aguilera, M. J. 1.; Tapia, V. L. M.; Vidales, I. F.; Salazar, S. G. 2005. Contenido nutrimental en suelo y hojas de aguacates en huertos establecidos en Michoacán y comparación de métodos para interpretación de resultados. Folleto Técnico $\mathrm{N}^{\circ} 2$. INIFAP. Uruapan, Mich, 28 p.

[2] Banuelos, J.; Trejo, D.; Lara, L.; Gavito, M. and Carreón, Y. 2013. Efecto de siete inóculos micorrízicos diferentes en Persea americana en suelo estéril y no estéril. Revista Tropical and Subtropical Agroecosystems, 16: 423 - 429.

[3] Bárcenas, A.; Almaraz, C.; Reyes, L.; Varela, L.; Lara, B.; Guillén, A.; Carreón, Y.; Aguirre, S. y Chávez, A. 2007. Diversidad de hongos micorrizógenosarbusculares en huertos de aguacate de Michoacán. Proceedings VI World Avocado Congress (Actas VI Congreso Mundial del Aguacate). Viña Del Mar, Chile. 12 - 16 Nov. 2007. ISBN No. 978-956-170413-8

[4] Bekker, T. F.; Labuschagne, N. and Kaiser, C. 2005. Effects of soluble silicon against Phytophthoracinnamomiroot rot of avocado (Perseaamericana Mill.) nursery plants. South African Avocado Growers' Association Yearbook. 28: 60-64.

[5] Brito, Giovani Greigh, Valdinei Sofiatti, Ziany Neiva Brandão, Vivianny Belo Silva, Franklin Magnum Silva and Dalva Almeida Silva. 2011. Non-destructive analysis of photosynthetic pigments in cotton plants. Acta Scientiarum. Agronomy Maringá. 33 (4): 671678.

[6] Brizuela-Amador Pérez, Basilio; Alcántar-González, Gabriel; Sánchez-García, Prometeo; Tijerina-Chávez, Leonardo; Castellanos-Ramos, Javier Z.; MaldonadoTorres, Ranferi. 2005. Nitratos en soluciones nutritivas en el extracto celular de pecíolo de chile. Revista Terra Latinoamericana. 23 (4): 469-476.

[7] Calderón, A. E. 1998. Fruticultura General. 3 ed. México, Editorial Limusa. p. 212-215; 579-606.

[8] Carreón, A. Y.; Aguirre, P. S.; Gavito, M. E.; Mendoza, S. D. J.; Juárez, C. R.; Martínez, T. M. y Trejo, A. D. 2014. Inoculación micorrizicoarbuscular en portainjertos de plantas de aguacate cv 'Hass' en viveros de Michoacán, México. Revista Mexicana de Ciencias Agrícolas. 5 (5): 847-857.

[9] Castellanos-Ramos, J. Z., S. Villalobos, J. L. Ojo de agua and P. Vargas. 2001. Determining fluid fertilizer nitrogen requirements in poblano pepper in Central Mexico. Instituto Nacional de Investigaciones
Forestales, Agrícolas y Pecuarias. Celaya, Guanajuato, México.

[10] Castro Alvarado, Edgar; Chávez Bárcenas, Ana Tztzqui; García Saucedo, Pedro Antonio; Reyes Ramírez, Leovigilda; Bárcenas Ortega, Ana Elizabeth. 2013. Effect of mycorrhizal inoculants in the development of mexican landrace avocado rootstocks. Tropical and Subtropical Agroecosystems. 16 (3): 407-413.

[11] Castro, M., Fassio, C., Cautin, R. y Ampuero, J. 2015. UCV7, Portainjerto de aguacate tolerante a salinidad. Rev. Fitotec. Mex. 38 (1): 85-92.

[12]Faust, M. 1989. Physiology of Temperate Zone Fruit Trees. John Wiley and Sons, Ed. U.S.A. p: 338.

[13] Finlay R. D. 2008. Ecological aspects of mycorrhizal symbiosis: with special emphasis on the functional diversity of interactions involving the extraradical mycelium. Journal of Experimental Botany, 59 (5):1115-1126.

[14]Fundora, S. L. R.; Rivera, E. R.; Martín, C. J. V.; Calderón, P. A.; Torres, H. A. 2011. Utilización de cepas eficientes de hongos micorrízicosarbusculares en el desarrollo de portainjertos de aguacate en un sustrato suelo cachaza. Revista Cultivos Tropicales. 32 (2): 23-29.

[15] García, E. 1988. Modificaciones al sistema de clasificación climática de Köppen. Universidad Nacional Autónoma de México, México D.F. p. 77.

[16] Gonsiorkiewicz J. P.; Silvia Capuani; José Félix de Brito Neto; NapoleãoEsberard de MacêdoBeltrão 2013. Indirect measurement of photosynthetic pigments in the leaves of Jatrophacurcas. RevistaCiênciasAgrárias, Londrina. 34 (2): 669-674.

[17] Jeffries, P. S., Gianinazzi, K. S., Perotto, K., Turnau, M., and Baera, J. M. 2003. The contribution of arbuscularmycorrhizal fungi in sustainable maintenance of plant health and soil fertility. Biology and Fertility Soils. 37:1-16.

[18] Jinwen, L.; Jingping, Y.; Dongsheng, L.; Pinpin, F.; Tiantai, G. Changshui, G. and Wenyue, C. 2011. Chlorophyll Meter's Estimate of Weight-based Nitrogen Concentration in Rice Leaf is Influenced by Leaf Thickness. Plant Prod. Sci. 14(2): 177-183.

[19] Killpack C. and D. Bucholz. 1993. Nitrogen in the environment: leaching. Extension. University of Missouri. St Louis MO. USA 3p.

[20] Larios, A.; Vidales, I.; Tapia, L. M.; Mendoza, M.; Guillen, H. y Hernández, A. 2011. Cultivo agroecológico del aguacate una opción sana y 
competitiva. Ed. Lap-Lambert. Alemania $1^{\mathrm{a}}$ edición. $270 \mathrm{p}$.

[21]Leyva, R. G.; Sánchez, G. P.; Alcántar G. G.; Valenzuela, U. J. G.; Gavi, R. F. y Martínez G. A. 2005. Nitrates content in cellular extracts of tomato petioles and fruits. Rev. Fitotec. Mex. 28 (2): 145-150.

[22] Márquez-Quiroz C., S.T. López-Espinosa, E. SánchezChávez, M.L. García-Bañuelos, E. De la Cruz-Lázaro, and J.L. Reyes-Carrillo. 2014. Effect of vermicompost tea on yield and nitrate reductaseenzyme activity in saladette tomato. Journal of Soil Science and Plant Nutrition. 14(1): 223-231.

[23] Reyes, A. J. C.; Alarcón, A. y Ferrera-Cerrato, R. 1997. Aspectos relacionados sobre el uso de la endomicorrizaarbuscular en aguacate (Persea americanaMill.). Fundación Salvador Sánchez Colín. CICTAMEX. S.C. Harinas, México. IRENAT. Colegio de Postgraduados. Montecillo, México. p 6878.

http://www.avocadosource.com/Journals/CICTAMEX /CICTAMEX_1997/ecol_2_97.pdf. Fecha de consulta: 09/02/2017.

[24] Reyes, J. C.; Ferrera-Cerrato, R. and Alarcón, A. 1998. Endomicorriza vascular, bacteria, vermicomposta en plántulas de aguacate en vivero. Memoria Fundación Salvador Sánchez Colín CICTAMEX S.C. Coatepec Harinas, México. pp. 12 -22.

[25] Rivera-Espinosa， R. A.; Martin Cárdenas，J. V.; Calderón Puig, A.; Torres Hernández, A. 2011. Utilización de cepas eficientes de hongos micorrízicosarbusculares en el desarrollo de portainjertos de aguacate en un sustrato suelo-cachaza. Revista Cultivos Tropicales. 32 (2):172-183.

[26] Salisbury, F. B. and Ross, C. W. 1994. Fisiología Vegetal. Grupo Editorial Iberoamérica S.A., México, $759 \mathrm{p}$.

[27] Seguel Fuentealba Alex. 2014. El potencial de las micorrizas arbusculares en la agricultura desarrollada en zonas áridas y semiáridas. Rev. IDESIA (Chile) 32 (1):3-8.

[28] Silveira, S. V.; de Souza, P. V. and Koller, O. C. 2002. Influência de fungos micorrízicosarbusculares sobre o desenvolvimento vegetativo de porta-enxertos de abacateiro Pesquisa agropecuaria brasileira. 37 (11) 1597-1604.

[29] Silveira, S. V.; De Souza, P. V. D.; Koller, O. C.; and Schwarz, S.F. 2003. Elementos minerales y carbohidratos en plantones de aguacate 'carmen' inoculados con micorrizas arbusculares. En Actas V Congreso Mundial del Aguacate. pp. 415-420.

[30] Tapia L. M.; Larios A.; Anguiano J. y Vidales L. 2007. Lixiviación de nitratos en dos sistemas de manejo nutricional y de agua en aguacate de Michoacán. Proceedings VI WorldAvocado Congress (Actas VI Congreso Mundial del Aguacate) Viña Del Mar, Chile. 12 - 16 Nov. 2007. ISBN No 978-956-170413-8.

[31] Tapia, V. L.M.; Larios, G. A; Anguiano, C. J. I; Vidales, F. I e Barradas, M.V. 2012. Lixiviación de nitratos y condición nutrimental en dos sistemas de manejo de riego y nutricional de aguacate (Persea americana MILL.). Rev. Int. Contam. Ambie. 28 (3):251-258.

[32] Tapia Vargas Luis Mario, Larios Guzmán Antonio, Hernández Pérez Anselmo y Guillén Andrade Héctor. 2014. Nutrición orgánica del aguacate cv. "Hass" y efecto nutrimental y agronómico. Revista Mexicana de Ciencias Agrícolas. 5(3):463-472

[33] Torres-Netto, A.; Campostrini, E.; Oliveira, J. G.; Yamanishi, O. K. 2002.Portable chlorophyll meter for the quantification of photosynthetic pigments, nitrogen and the possible use for assessment of the photochemical process in Carica papaya. Brazilian Journal of Plant Physiology. 14 (3):203-210.

[34] Torres Netto, A.; Campostrini, E.; Oliveira, J. G.; Smith, R. E. B. 2005. Photosynthetic pigments, nitrogen, chlorophyll a fluorescence and SPAD-502 readings in coffee leaves. Scientia Horticulturae. 104 (2):199-209.

[35] Trinidad S. A., Guzmán, S. J., Mena T. L. 2015. Abonos orgánicos en la producción de guayaba (Psidiumguajava L.) en la Región Oriente del Estado de Michoacán. Coordinadora Nacional de las fundaciones Produce, A. C.; Unidad Operativa Michoacán; comité sistema Producto Guayaba y Colegio de Postgraduados. Campus Montecillo, Texcoco, Estado de México. 93 p. 